\title{
Factors Affecting Derivatives Use for Life Insurance Companies
}

\author{
Park Kwang Hee ${ }^{1} \&$ Woon Kyung Song ${ }^{1}$ \\ ${ }^{1}$ Dept. of Business Administration, Korea Aerospace University, Korea \\ Correspondence: Woon Kyung Song, Professor, Dept. of Business Administration, Korea Aerospace University, \\ Korea.
}

Received: January 19, 2017

Accepted: February 14, 2017

Online Published: November 15, 2017

doi:10.5539/ijef.v9n12p168

URL: https://doi.org/10.5539/ijef.v9n12p168

\begin{abstract}
The aim of this article is to investigate what factors affect derivatives use for life insurance companies in Korea. For life insurance companies in Korea, there are some problems to solve. First one is to meet IFRS standard which emphasizes solvency. Second one is to overcome problems from macroeconomic including low economic growth and low interest rate, fluctuating foreign currency exchange rate, and problems from population composition change and longer longevity. One of the possible ways to control the risks that life insurance companies face is using derivatives. Traditionally life insurance companies use reinsurance to hedge their inherent risks. However, hedging by using derivatives provides some different merits from those by reinsurance, such as, effects of controlling risks from macroeconomic change, in some cases less costs to control risks, etc. So using derivatives to control risks for life insurance companies is not only for sustainable management but for growth and becoming more competitive. The study results show that asset size, foreign assets and liabilities, proportion of deposit insurance, liquidity, RBC are significant factors affecting derivatives use.
\end{abstract}

Keywords: derivatives, life insurance company, regression analysis, deposit insurance

JEL: F65, G22, G32, G13, N25

\section{Introduction}

Deriavtives markets in Korea started in May 1996 by taking market place KOSPI200 futures public. The derivatives market size has grown vary rapidly in Korea, in 2011 trade volume was number one in the world. However, since then leave of institutional investors and thus unbalance between investors, skewed trade pattern, trade volume shrink have made the market slow. Derivatives markets not only contribute to financial market in a country but also cause turmoil in the market. Subprime crisis in 2008 was mainly due to trades of subprime mortgage credit risk. Despite the global financial crisis, the size of derivatives market has been growing continuously. Derivatives were initially devised to control the risk of price fluctuation of underlying assets. Risk hedge by derivatives is very useful risk control method in that the systematic risk that cannot be got rid of by diversified investment can be reduced. Also, unlike traditional financial instruments, cash flow between the parties to transaction does not occur or only small amount of cash is required as deposit money, it increases the elasticity of application of funds. On the other hand, the leverage effect of derivatives contract from small size deposit money requires extra risk management due to its destructive power.

In this study, we investigate derivatives application by life insurance companies in Korea. Life insurance companies which deal with risks of others conducts risk management from designing insurance product stage and after sales of the product continuously indispensably. Especially reinsurance in the insurance industry that can provide insurers risk diversification effects push for insurers extra risk management activities including using derivatives.

However, the environment is quite different from other countries in that the rate of speed of aging has been unprecedentedly fast, fluctuation of interest rate and currency rate has been higher that most other countries and growth of economy has been slow. Due to those reasons that make hard to forecast the future the traditional risk management methods have not been enough. Reflecting those things most life insurance companies have managed risks using derivatives. In this research, we investigate factors affecting life insurers' risk management using derivatives.

\section{Precedent Studies}

Regarding derivatives, many studies have been conducted. Jung et al. (1996) show that companies use 
derivatives to hedge risks from currency rate, interest rate and fluctuation of goods prices instead of speculating purposes. Ban et al. (2004) argue that liquidity, progressive corporate tax rates, foreign debt have positive effect in derivative use but opportunity chance and manager attraction reward have no effect on derivative use for smaller companies, and there is negative correlation between financial risk and derivative use, while for large companies there is positive correlation between liquidity and derivative use. Cho (2001) insists that for life insurance companies asset size, foreign asset ratio, ratio of deposit insurance to total insurance are positively related to derivatives at 5\% significant level, while reinsurance ratio is significant at $10 \%$ significant level.

Lee(2003) show that Korea's firms use the financial derivatives more when they have more profits and losses in terms of foreign currency. Second, Korea's firms use the financial derivatives more when they export more. Third, if they decided to use the financial derivatives, then they use more when they have more foreign liabilities. The firms which use relatively more use less financial derivatives as they have more foreign exchange loss. Jung B. S. (2008) argues that firms usually use derivatives to minimize the financial distress effects and to solve their liquidity problems with regard to investment opportunity and to hedge against the risk arising from volatilities in foreign exchange rate. The author also shows that firm size, leverage, foreign currency assets, foreign currency debts, foreign revenue affect derivative use.

Jung (2005) insists that there is strong evidence size, liquidity, and the rate of loan and debt to total assets are positively related to the use of derivatives, however, net interest income is negatively related to the use of derivatives. The author argues that if banks are practicing coordinated risk management, then the use of derivatives to hedge interest-rate risk and foreign-exchange risk should also be related to bank's credit and foreign currency exposure. But, there is no statistically significant evidence that Korean commercial banks are engaging in coordinated management of interest-rate risk and foreign-exchange risk.

Kim (2008) shows banks use for controlling liquidity problems, credit risks, default risks, and BIS problems. In addition to that banks use derivatives for trade purposes. Park and Kim (2010) argue that banks can use derivatives either to hedge against unexpected changes in interest rates, foreign-exchange rates, commodity prices or to speculate on the future movements of these economic variables. According to the two studies, banks use derivatives not only for risk management but also for trade purposes. The principle is that risk transfer happens only when the counter part that will accept the risk exists. Therefor the study results that banks use derivatives indicate that banks act risk acceptance role. And by the role the derivatives market has been growing.

Mian (1996) showed that there was not clear proof of the relationship between the growth opportunity and hedging but showed that hedging was related to firm size. Also, firms in the regulated industry have less amount of motive to use derivatives due to reduced costs of funds from outside. So, using derivatives may not be so attractive to the life insurance industry which is one of the most heavily regulated industries.

Cloquitt and Hoyt (1997) argue that the larger the size of asset the more the company uses derivatives. The results may be similar to those of banks that banks pursue the economy of scale or may be due to the size of risk exposed to interest rate variability. The authors insist that corporation type life insurer use more derivative than mutual type life insurer.

Grosen and Jørgensen (2000) analyzed the determinants of financial derivatives use in the United Kingdom life insurance industry. The results indicate that the propensity to use derivative instruments is positively related to a firm's size, leverage and international links, and negatively related to the extent of reinsurance. Also the authors find that mutual life insurance firms have a greater propensity than stock firms to use derivatives. The positive relationship between leverage and derivatives use and the negative relationship between reinsurance and derivatives use supports the hypothesis that U.K. life insurers use derivatives to offset risk, rather than as a speculative means of income generation. Firm size and organizational form are the main influences on the extent of financial derivatives use.

Cummins, Phillips, and Smith (1997) find evidence consistent with the use of derivatives by insurers to hedge risks posed by guaranteed investment contracts (GICs), collateralized mortgage obligations (CMOs), and other sources of financial risk.

De Ceuster, Flanagan, Hodgson, and Tahir (2003) conducted empirical tests and the results for the Australian life insurance industry in general confirm the findings of UK and US based research. However, the Australian general insurance industry does not appear to follow the conclusions of previous literature. The authors' results indicate that for life insurers, the determinants of derivatives use were size, leverage and reinsurance. For the general insurance industry the determinants were size and the extent of long tail lines of business written. As regards the determinants of the extent of derivative usage, these were size and asset-liability duration mismatches for life insurers. For the general insurance industry the determinants of the extent of derivative usage 
were size, the extent of long tail lines of business written, and the reporting year.

\section{Research Design}

\subsection{Hypothesis and Variables}

According to precedent researches the firm size affects derivative use. That is, the larger the firm size the more risk associated with asset management, and thus the more derivative use. For life insurance company, as the size of asset grows, the necessity to control risks related to interest rate variation become bigger. Also for assets invested to other countries currency rate change risk should be monitored and managed. On the other hand, life insurance companies with large size assets can have more chances to manage risks by other methods such as diversified investment, which results in less use of derivative.

Hi: Asset size affects derivative use.

Some of the life insurance company management characteristics can affect its use of derivatives. Leverage, foreign assets and liabilities written in foreign currency, reinsurance cost are selected as life insurance management characteristics. Life insurance companies usually have high leverage, hold foreign assets and liabilities for asset management. Also to diversify undertaken risks of customers life insurance companies utilize reinsurance. High leverage can increase the rate of both profit rate and loss rate, which indicates risk management for leverage is necessary.

H2: Leverage affects derivative use.

If the amount of foreign assets and liabilities written in specific foreign currency are the same, the investor, in this case a life insurance company, does not need to hedge risks from the variability of the currency rate. However, if the amount is not the same as usual risks from currency change should be managed. Thus we advance the following hypothesis

H3: Foreign assets and liabilities written in foreign currencies affect derivative use.

Life insurance companies have managed risks by reinsurance. Especially for short-term whole life insurance products, life insurance companies need not use derivative for control risks from interest rate and currency rate variability. However, for long-term policies, controlling risks from assets management caused by fluctuation of interest rate and foreign currency rate is necessary to maturity. For controlling those risks, derivatives use can be a substitute for or supplement to reinsurance. Thus we assume that the cost of reinsurance can affect the use of derivative.

\section{H4: Reinsurance cost affects derivative use.}

Also some of the business characteristics of life insurance itself can affect derivatives use of life insurance companies. As business characteristics, variables of increase rate of incoming premium, component ratio of deposit insurance policies, invalidity, non-perform assets, business expense ratio are selected. Among those factors we choose increase rate of incoming premium and component ratio of deposit insurance policies because the more the incoming premium the more risks a life insurance company has to control and the more the deposit policies sold the loner period and the more risks a life insurance company has to control. Also the life insurance industry is heavily regulated in terms of liquidity and solvency. Most life insurance companies all over the world including those in Korea face IFRS regulation. So life insurance companies are very sensitive to factors influencing liquidity and solvency. Therefore, liquidity and RBC are selected as variables to affect derivatives use.

H5: Increase rate of incoming premium, component rate of deposit insurance policies affect derivatives use.

H6: Liquidity and RBC affect derivatives use.

\subsection{Definition of Variables}

To measure the variables, we define the variables as follow.

Table 1. Variables and method to measure

\begin{tabular}{llll}
\hline Division & Variables & Term & Measure \\
\hline Dependent Var. & Derivatives Use & DervUse & Trade amount of derivatives/total assets \\
Firm size & Asset size & LnAsset & Natural log of asset size \\
Managememt & Leverage & DebtRatio & Debt/total assets \\
Characteristics & Foreign assets & FADRatio & (Foreign assets + foreign liabilities)/ total assets \\
& Foreign liabilities & & \\
\hline
\end{tabular}




\begin{tabular}{llll}
\hline & Reinsurance costs & ReinsCost & Reinsurance premium/total assets \\
Business & Sales growth & SalesGrowth & Rate of increase of incoming premium \\
Characteristics & Deposit insurance ratio & DepRatio & Premium income from deposit insurance/ total premium income \\
& Liquidity & Liquidity & Liquid assets/insurance paid \\
& RBC(Risk backed capital) & RBC & Solvency margin (solvency margin amount/standard solvency margin amount \\
\hline
\end{tabular}

\subsection{Equation for Analysis}

The multivariate equation to analyze factors affecting derivatives use for life insurance companies is as follows.

$$
\begin{gathered}
\text { DerivUse }=\beta_{0}+\beta_{1} \text { LnAsset }+\beta_{2} \text { DebtRatio }+\beta_{3} \text { FADRatio }+\beta_{4} \text { ReinsCost }+\beta_{5} \text { SalesGrowth }+ \\
\beta_{6} \text { DepRatio }+\beta_{7} \text { Liquidity }+\beta_{8} R B C+\varepsilon
\end{gathered}
$$

\subsection{Data and Model}

The data period is from the first quarter of 2011to $4^{\text {th }}$ quarter of 2016. The data was collected from official data of Korea life insurance association and the Financial Supervisory of Korea. The data is panel type data which consists of both cross sectional type data and time series type data. In that case, fixed effect model and random effect model are available to adopt. For this analysis, we adopt random effect model because some data are time invariant which fixed effect model has limit to analyze.

\section{Results}

\subsection{Basic Statistic}

The basic statistics of the data is as follows.

\begin{tabular}{|c|c|c|c|c|c|c|}
\hline Year & Variable & Average & Std. Dev. & Mid. & Min. & $\operatorname{Max}$ \\
\hline \multirow[t]{9}{*}{2011} & DervUse & 0.041 & 0.046 & 0.018 & 0.000 & 0.198 \\
\hline & LnAsset & 16.012 & 1.892 & 15.43 & 13.789 & 18.902 \\
\hline & DebtRatio & 0.921 & 0.348 & 0.976 & 0.689 & 0.986 \\
\hline & FADRatio & 0.013 & 0.074 & 0.018 & 0.028 & 0.210 \\
\hline & ReinsCost & 0.054 & 0.012 & 0.012 & 0.001 & 0.054 \\
\hline & SalesGrowth & 0.198 & 0.864 & 0.086 & -0.0076 & 0.621 \\
\hline & DepRatio & 0.532 & 0.223 & 0.426 & 0.587 & 0.943 \\
\hline & Liquidity & 5.792 & 11.886 & 2.786 & 0.000 & 137.44 \\
\hline & $\mathrm{RBC}$ & 2.198 & 2.546 & 2.887 & 0.892 & 7.927 \\
\hline \multirow[t]{9}{*}{2012} & DervUse & 0.038 & 0.051 & 0.023 & 0.000 & 0.201 \\
\hline & LnAsset & 16.543 & 1.964 & 15.68 & 13.812 & 18.976 \\
\hline & DebtRatio & 0.937 & 0.458 & 0.914 & 0.743 & 0.982 \\
\hline & FADRatio & 0.017 & 0.092 & 0.021 & 0.032 & 0.212 \\
\hline & ReinsCost & 0.048 & 0.008 & 0.011 & 0.002 & 0.061 \\
\hline & SalesGrowth & 0.172 & 0.986 & 0.089 & -0.078 & 0.653 \\
\hline & DepRatio & 0.572 & 0.185 & 0.423 & 0.610 & 0.986 \\
\hline & Liquidity & 6.028 & 14.328 & 2.342 & 0.000 & 165.36 \\
\hline & $\mathrm{RBC}$ & 2.718 & 2.876 & 2.654 & 0.912 & 8.213 \\
\hline \multirow[t]{9}{*}{2013} & DervUse & 0.029 & 0.065 & 0.021 & 0.000 & 0.187 \\
\hline & LnAsset & 16.798 & 2.012 & 16.02 & 13.478 & 19.012 \\
\hline & DebtRatio & 1.108 & 0.234 & 0.912 & 0.210 & 0.992 \\
\hline & FADRatio & 0.021 & 0.048 & 0.019 & 0.033 & 0.198 \\
\hline & ReinsCost & 0.062 & 0.014 & 0.010 & 0.001 & 0.056 \\
\hline & SalesGrowth & 0.163 & 0.58 & 0.091 & -0.045 & 0.624 \\
\hline & DepRatio & 0.498 & 0.216 & 0.512 & 0.554 & 0.923 \\
\hline & Liquidity & 6.13 & 13.980 & 2.872 & 0.000 & 164.76 \\
\hline & $\mathrm{RBC}$ & 2.887 & 3.012 & 2.811 & 0.878 & 9.348 \\
\hline
\end{tabular}

Table 2. Basic statistics 


\begin{tabular}{llccccc}
\hline 2014 & DervUse & 0.037 & 0.054 & 0.018 & 0.000 & 0.188 \\
& LnAsset & 17.210 & 2.212 & 16.35 & 14.120 & 19.123 \\
DebtRatio & 0.967 & 0.42 & 0.892 & 0.732 & 0.879 \\
& FADRatio & 0.023 & 0.064 & 0.018 & 0.041 & 0.231 \\
ReinsCost & 0.049 & 0.013 & 0.012 & 0.002 & 0.062 \\
& SalesGrowth & 0.105 & 0.498 & 0.086 & -0.012 & 0.598 \\
& DepRatio & 0.515 & 0.197 & 0.401 & 0.712 & 0.947 \\
& Liquidity & 5.132 & 12.885 & 2.879 & 0.000 & 187.22 \\
& RBC & 1.987 & 2.812 & 2.213 & 0.988 & 8.563 \\
\hline DervUse & 0.042 & 0.04 & 0.022 & 0.000 & 0.207 \\
& LnAsset & 17.131 & 1.684 & 16.82 & 14.657 & 19.326 \\
& DebtRatio & 0.873 & 0.282 & 0.873 & 0.212 & 0.912 \\
& FADRatio & 0.028 & 0.066 & 0.019 & 0.032 & 0.214 \\
ReinsCost & 0.059 & 0.018 & 0.010 & 0.003 & 0.058 \\
& SalesGrowth & 0.101 & 0.95 & 0.084 & -0.014 & 0.487 \\
DepRatio & 0.601 & 0.226 & 0.376 & 0.458 & 0.921 \\
& Liquidity & 5.421 & 14.768 & 2.679 & 0.000 & 178.96 \\
RBC & 2.981 & 3.014 & 2.336 & 0.912 & 9.310 \\
\hline
\end{tabular}

From the above table, we can see that derivatives use has not been changed so much. The asset size has been growing continuously. Also there have been not big fluctuations about leverage, foreign assets and liabilities, reinsurance costs, proportion of deposit insurance to total insurance, and RBC. However, sales growth has been changed pretty much.

\subsection{The Regression Test Results}

Table 3. Results of regression analysis

\begin{tabular}{|c|c|c|c|c|c|c|c|}
\hline \multirow[t]{2}{*}{ Model } & \multicolumn{2}{|c|}{ Nonstandard coefficient } & \multirow{2}{*}{$\begin{array}{c}\text { Standard coefficient } \\
6 \\
\end{array}$} & \multirow[b]{2}{*}{$\mathrm{t}$} & \multirow[t]{2}{*}{ Significance probability } & \multicolumn{2}{|c|}{ Multicollinearity } \\
\hline & 8 & Stndrd error & & & & Tolerance & VIF \\
\hline constant & -.213 & .242 & & -.612 & .541 & .430 & 2.012 \\
\hline LnAsset & .014 & .008 & .109 & 2.773 & .043 & .430 & 2.042 \\
\hline DebtRatio & -.112 & .212 & -.048 & -.486 & .512 & .578 & 1.872 \\
\hline FADRatio & .498 & .086 & .465 & 4.898 & .000 & .622 & 1.672 \\
\hline ReinsCost & .783 & .912 & .173 & .985 & .289 & .458 & 2.014 \\
\hline SalesGrwth & .018 & .056 & .028 & .428 & .652 & .608 & 1.562 \\
\hline DepRatio & .088 & .054 & .187 & 2.687 & .049 & .634 & 1.721 \\
\hline Liquidity & -0.0097 & .078 & -.0076 & -2.67 & .012 & .721 & 1.854 \\
\hline $\mathrm{RBC}$ & .00081 & .0034 & .0054 & 6.53 & .000 & .234 & 1.986 \\
\hline
\end{tabular}

From the table, LnAsset, FADRatio, DepRatio, Liquidity, and RBC are turned out to affect the derivatives use of life insurance companies. Precedent studies such as Cho (2001), Mian (1996), Cloquitt and Hoyt (1997) show that size of asset for life insurance company influences the derivatives use. The result that Foreign assets and liabilities affect significantly derivatives use for life insurance companies is consistent with the results of many studies including Cho (2001), Lee (2003), Berkman and Bradbury (1996).

DepRatio which measures the proportion of deposit insurance policies to total insurance is one of the major sources of risk that insurance companies face. Some life insurance companies have guaranteed certain level of interest rate to the savings account of policy holders. However as the growth of domestic economy has slowed down and opportunities to invest have become shrunk, some life insurance companies have had difficulties to satisfy the level of interest rate that they guaranteed. On the other hand, as the longevity has grown, less insurance money has paid out to fiduciaries. Overall, for life insurance companies as the amount of deposit insurance sold, the more use of derivatives use was expected for controlling risks. And the result is the same as expected.

The main concern of the Financial Supervisory is solvency of life insurance companies. Therefore factors affecting solvency are also life insurance companies' concern. In terms of solvency, liquidity and RBC are two most important factors affecting solvency of life insurance companies. So life insurance companies try to 
manage liquidity and RBC using many methods including derivatives. In this way, liquidity and $\mathrm{RBC}$ are expected to affect derivatives use of life insurance companies and the results were turn out to be the same.

\section{Conclusion}

Life insurance companies in Korea are facing harsher atmosphere than ever before due to rapidly changing population composition and longevity, macroeconomic condition, global socioeconomic condition, and strict regulation. To overcome the problems and make competitive, life insurance companies have made efforts including developing new marketing channel, new markets, new investing, appropriate insurance products, and managing skill. Along with these efforts, life insurance companies have worked hard to control risks, realizing that controlling risks can bring many advantages including firm value increase. The traditional and specific risk hedging method for life insurance companies has been reinsurance. However, the types of risks that life insurance companies are facing have been changed from traditional paradigmatic risks coming from increased death rate or interest change etc. to new types of risks coming from composition of population, rapid aging, low interest rates, changing currency exchange rate etc. So life insurance companies have to find new methods to come up with these new types of risks and one of the methods is using derivatives.

Life insurance companies have used derivatives to protect themselves from risks, and in this research we investigated factors affecting their determining derivatives use. The study results show that asset size, foreign assets and liabilities, deposit insurance, liquidity, and RBC affect derivatives use. Among the variables, foreign assets and liabilities and deposit insurance are worth considering. As the average longevity becomes longer, life insurance companies liabilities to pay insurance money can be postponed which is good news to them. However, for deposit insurance with guaranteed certain level of interest rate, life insurance company has to earn higher rate of return from somewhere else to satisfy the guaranteed level of interest rate under low growth economic condition. Such unexpected conditions make life insurance companies use derivatives.

Investing in foreign countries and financing from foreign investors is inevitable for life insurance companies in terms of higher returns and lower financing costs. The problem is that additional risks from currency exchange rate change and interest rate of the foreign countries change follow. To reduce the risks life insurance companies use derivatives.

In the age of longer life span, the roles of life insurance companies should be changed. They should do annuity related business more and various consulting business in terms of designing personal finance planning etc. However, before that life insurance companies try to sustain and make themselves competitive. Using derivatives is one of good methods reducing risks but managing derivatives use requires additional tasks including raising competent employees for the job.

\section{References}

Ban, H. J., \& Kim, J. K. (2004). The Determinants of Hedging with Derivatives. Korea Business Review, 33(1), 25-49.

Colquitt, L. L., \& Hoyt, R. E. (1997). Determinants of corporate hedging behavior: Evidence from the life insurance industry. Journal of Risk and Insurance, 649-671. https://doi.org/10.2307/253890

Cummins, J. D., Phillips, R. D., \& Smith, S. D. (1997). Corporate hedging in the insurance industry: The use of financial derivatives by US insurers. North American Actuarial Journal, 1(1), 13-40. https://doi.org/10.1080/10920277.1997.10595582

De Ceuster, M., Flanagan, L., Hodgson, A., \& Tahir, M. I. (2003). Determinants of derivative usage in the life and general insurance industry: The Australian evidence. Review of Pacific Basin Financial Markets and Policies, 6(04), 405-431. https://doi.org/10.1142/S0219091503001146

Grosen, A., \& Jørgensen, P. L. (2000). Fair valuation of life insurance liabilities: the impact of interest rate guarantees, surrender options, and bonus policies. Insurance: Mathematics and Economics, 26(1), 37-57. https://doi.org/10.1016/S0167-6687(99)00041-4

Jung Heon-Yong. (2005). Use of Derivatives by Korean Banks. Journal of Korean Business Education, 38, 447-459.

Jung, B. S. (2008). The Determinants of Derivatives Use: Evidence from KRX Listed Companies. Ph.D. Dissertation, SKK University.

Jung, D. Y., \& Ki, J. (1996). Analysis on real conditions of domestic firms' derivatives use. The Korean Journal of Financial Studies, 3(1), 163-177. 
Kim, S. H. (2008). A Study of Using Derivatives in Domestic Financial Institutions and Amendments of Tax Policy. Ph.D dissertation, HanYang University.

Lee, J. D. (2003). Foreign Exchange Exposure and Hedging Determinant of Derivatives of International Transaction Firms. Journal of International Business, 14(3), 1.

Park, J. Y., \& Kim, Y. J. (2010). The Effects of Financial Characteristics on Trading Activities of Financial Derivatives. Journal of Industrial Economics and Business, 23(1), 145-166.

\section{Copyrights}

Copyright for this article is retained by the author(s), with first publication rights granted to the journal.

This is an open-access article distributed under the terms and conditions of the Creative Commons Attribution license (http://creativecommons.org/licenses/by/4.0/). 